\title{
Author Correction: True equilibrium measurement of transcription factor-DNA binding affinities using automated polarization microscopy
}

\author{
Christophe Jung ${ }^{1}$, Peter Bandilla ${ }^{1}$, Marc von Reutern ${ }^{1}$, Max Schnepf ${ }^{1}$, Susanne Rieder ${ }^{1}$, Ulrich Unnerstall ${ }^{1}$ \& \\ Ulrike Gaul ${ }^{1}$
}

Correction to: Nature Communications https://doi.org/10.1038/s41467-018-03977-4; published online 23 April 2018

In the original version of this Article, equation 3 contained a sign error whereby the term RT was added when it should have been subtracted. This has now been corrected in the PDF and HTML versions of the Article.

Published online: 05 February 2019

\footnotetext{
(c) (i) Open Access This article is licensed under a Creative Commons Attribution 4.0 International License, which permits use, sharing, adaptation, distribution and reproduction in any medium or format, as long as you give appropriate credit to the original author(s) and the source, provide a link to the Creative Commons license, and indicate if changes were made. The images or other third party material in this article are included in the article's Creative Commons license, unless indicated otherwise in a credit line to the material. If material is not included in the article's Creative Commons license and your intended use is not permitted by statutory regulation or exceeds the permitted use, you will need to obtain permission directly from the copyright holder. To view a copy of this license, visit http://creativecommons.org/licenses/by/4.0/.
}

() The Author(s) 2019

\footnotetext{
${ }^{1}$ Gene Center and Department of Biochemistry, Center for Integrated Protein Science Munich (CIPSM), Ludwig-Maximilians-Universität München, FeodorLynen-Strasse 25, 81377 München, Germany. Correspondence and requests for materials should be addressed to C.J. (email: jung@genzentrum.Imu.de)
} 